\title{
Betablockers for haemodynamically stable acute myocarditis
}

\author{
Lorenzo Monti ${ }^{1,2^{*}}$, Claudio Moro ${ }^{3}$, Lucia Occhi ${ }^{2}$, Veronica Lisignoli ${ }^{2,1}$, Giuseppe lacuitti ${ }^{3}$, Daniela Pini ${ }^{2}$, \\ Barbara Nardi ${ }^{1,2}$, Maddalena Lettino ${ }^{2}$, Luca Balzarini ${ }^{1}$ \\ From 17th Annual SCMR Scientific Sessions \\ New Orleans, LA, USA. 16-19 January 2014
}

\section{Background}

No therapy is actually recommended for hemodynamically stable acute myocarditis patients. However, most patients are discharged on empiric therapy. We sought to evaluate any eventual effect of medical therapy on left ventricular ejection fraction (LVEF) at f.u.

\section{Methods}

We analyzed CMR data form 44 patients hospitalized from our E.D. with acute myocarditis (diagnostic CMR performed after a mean of 5 days after admission, f.u. CMR after a mean of 5,4 months).

\section{Results}

baseline LVEF was similar ( $\mathrm{p}=0.2)$ between ACE e BB groups, $61.9 \pm 5 \%$ and $58,3 \pm 7 \%$ respectively. DUAL group had a lower mean LVEF of $54 \pm 11 \%$. At follow up, LVEF was unchanged in ACE group ( from 61.9 to $61.2 \%$ ), and improved in BB group, from 58 to $63 \%$ ( $\mathrm{p}=$ $0,04)$. In DUAL group LVEF improved in a similar extent from 54 to $59 \%$ (p 0,01). Myocardial T2 STIR edema, significantly decreased at f.u. in all groups. All the remaining CMR parameters had non-significant modification from baseline to f.u.; LGE mass showed borderline significance toward reduction $(\mathrm{p}=0.066)$.

\section{Conclusions}

With the limitation of the small sample size of our series of hemodynamically stable acute myocarditis, we observed a greater improvement of LVEF at 6 months in pts treated with betablocker therapy, irrespective of concomitants ACEi therapy.

${ }^{1}$ Radiology, Humanitas Research Hospital, Rozzano(MI), Italy

Full list of author information is available at the end of the article

\section{Funding}

None.

\section{Authors' details}

${ }^{1}$ Radiology, Humanitas Research Hospital, Rozzano(MI), Italy. ${ }^{2}$ Cardiology, Humanitas Research Hospital, Rozzano, Ml, Italy. ${ }^{3}$ Cardiology, P.O. Desio, Desio, MB, Italy.

Published: 16 January 2014

doi:10.1186/1532-429X-16-S1-P277

Cite this article as: Monti et al:: Betablockers for haemodynamically stable acute myocarditis. Journal of Cardiovascular Magnetic Resonance 2014 16(Suppl 1):P277.
Submit your next manuscript to BioMed Central and take full advantage of:

- Convenient online submission

- Thorough peer review

- No space constraints or color figure charges

- Immediate publication on acceptance

- Inclusion in PubMed, CAS, Scopus and Google Scholar

- Research which is freely available for redistribution
() Biomed Central

\section{Biomed Central}

